\title{
Strategy Evaluation for accelerating the solar marketing
}

\author{
*Dr. Gurubheemachar.B ${ }^{1}$, Kailash Krishna Prasad.B ${ }^{2}$ \\ ${ }^{1}$ (Head of the Department of Economics, S.B.S.Y.M Degree College, Kurnool, A.P, India) \\ ${ }^{2}$ (Assistant Professor, Department of EEE, BITS-Kurnool, A.P, India)
}

\begin{abstract}
It is inevitable that, in the forth coming days, the usage of solar energy based products and utilities will be gradually stepped up. So far as global marketing strategies are concerned, solar marketing has got huge potential to survive and excel in this highly competitive market environment. In order to mitigate the present day energy demand, it is of utmost important to depend upon the abundantly available nonconventional energy source like solar energy. Solar energy based Technology is termed to be as a clean technology. Creating awareness among the people on harvesting of solar energy will help in mitigating the needs of energy crisis to a considerable extent. Also, the set up of the solar energy based companies should be encouraged in large scale to raise the economic stature of the society. The main objective of this paper is to focus on development of market strategies for solar marketing and its benchmarking with the existing technology.
\end{abstract}

Keywords: Benchmarking, Clean Technology, Competitive market, Economic Stature and Solar marketing.

\section{Introduction to Solar power}

The solar energy has many advantages that help in developing the solar marketing strategies. The solar photovoltaic panels and thermal energy based flat solar plate solar collectors are getting more popular now-adays because of the fact that, they produce clean energy without making any noise. The flat plate solar collectors and concentrated type of solar collectors capture the solar power and converts the light energy into heat energy which one can utilize to heat the water mainly used for house hold purposes whereas the solar Photovoltaic panels converts the light energy directly into electrical energy which can be used for electrifying our houses. The solar energy has got huge potential to serve as a primary source of energy [1].

The solar market has to be still accelerated further yet by gaining the confidence among the customers $[2,3]$. The customers are having lack of knowledge regarding the reliability of solar energy based products and it is the duty of the solar energy based companies to reach the public and explaining the prospects of solar utilities. The sales process of solar energy based products has become still an extremely difficult. Awareness should be created among the public about the factors like raise in utility monthly bills, increase in the fuel costs, encouraging the eco-friendly technology etc. So, the solar sales have to be enhanced ensuring the emission free environment to the maximum possible extent.

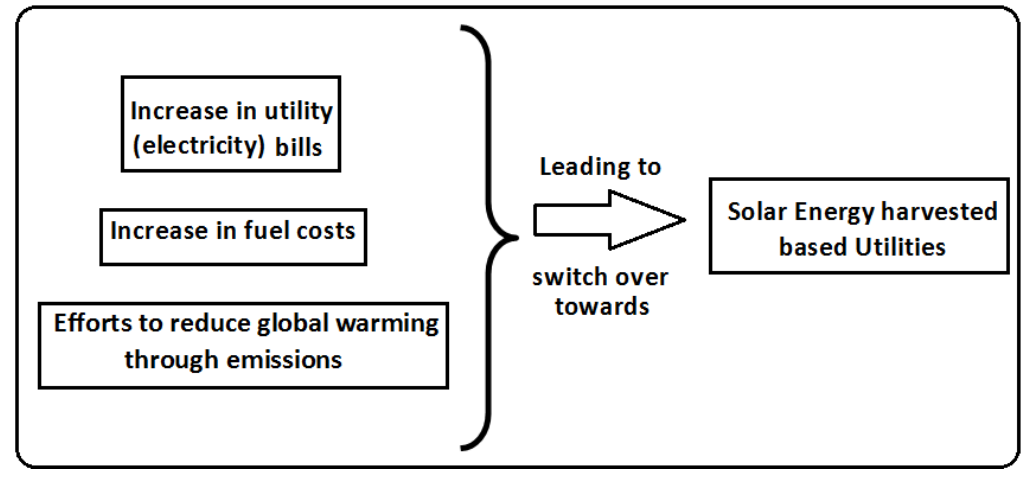

Fig. 1: Reasons to prefer solar energy based Utilities

\section{Factors affecting Solar Marketing}

There exist several factors that are mainly influencing the present day consumers to show reluctance towards purchasing of solar energy based products and services. The factors which mainly affecting the solar marketing are depicted in Fig. 2. There is of utmost importance to educate the public about the reliability and merits of the solar marketing which in turn helps both companies (in terms of profits and survival) and the consumers to meet the present day energy demand. As mentioned above about the rise in fuel rates, increase in global emissions, it is the responsibility of the public to mitigate the issues by encouraging towards the purchase of solar products and enhancing the solar sales. 


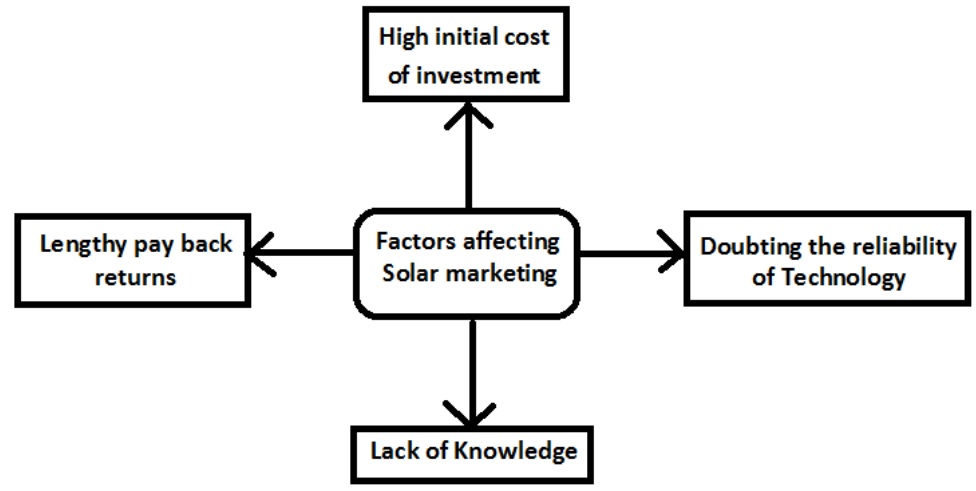

Fig. 2: Factors affecting solar market

(i) High Initial cost: The initial investment to install the solar technology is little bit high. This is the main reason which making the public to show reluctance to go this technology.

(ii) Doubting the Reliability: The efficiency of the solar technology is still not convincingly reaching to the consumers. The consumers having the pessimistic thinking that, whether the technology works good or not.

(iii) Inadequacy of Knowledge: There exist lack of technical know-how about the solar technology and prospects.

(iv) Lengthy Pay back returns: The investment on the solar technology leads to long pay back periods to get our money back. This also creating negative impact among the public to encourage the solar utilities.

\section{Solar marketing strategies to boost up its sales}

There are several strategies mainly intended to boost up the sales and marketing of solar products and utilities. Few of them are mentioned below.

1) Making solar products cost effective and reaching the consumers with low prices

2) Creating awareness to the consumers by developing solar products based website so that customer can follow the concerned websites regarding the prices, technology updates. The website should be designed in an attractive way including the graphical effects so that people get attracted with the products and utilities.

3) Creating Blogging websites so that people start interacting with solar experts and get required Information about the solar based updates.

4) By Email marketing people come in touch with the solar marketing team making things little bit easier to do marketing.

5) Social media like facebook, twitter and whatsapp applications will create lot of impact on solar marketing and its sales.

6) By educating the consumers by giving demo on the solar products will improve the sales since the People get confidence on the performance of the technology.

7) The word - of - mouth referrals also creates interest on solar marketing.

8) Encouraging the co-marketing i.e., combining with other companies and ensuring joint marketing strategies will also help the solar marketing.

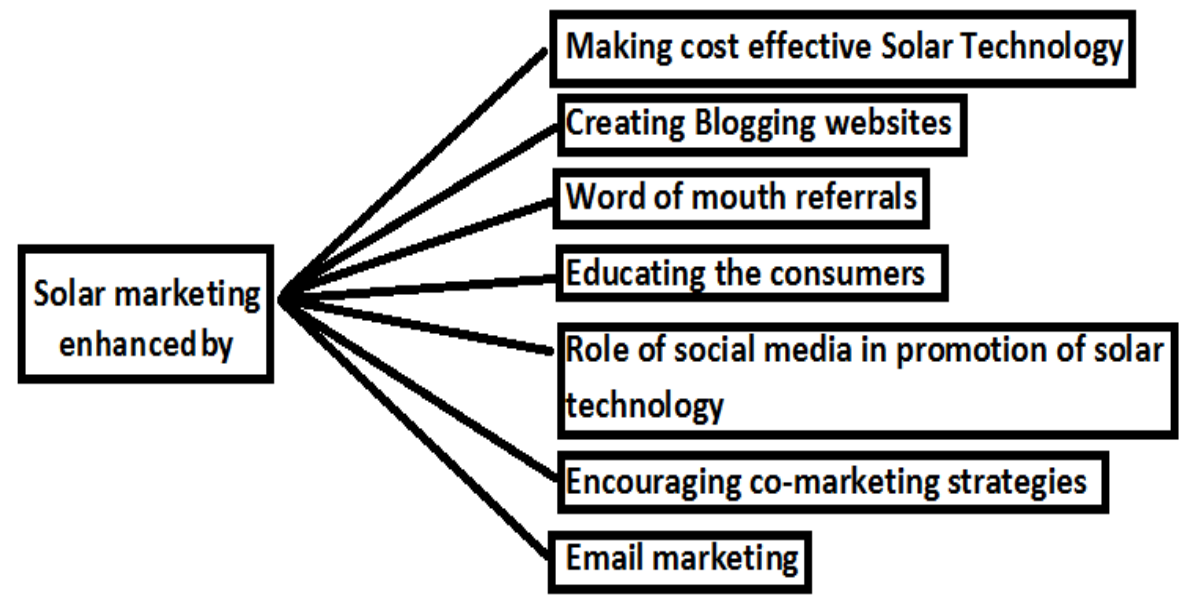

Fig. 3: Solar marketing Strategies 


\section{Advantages of Solar Technology}

Solar technology is abundantly available with free of cost. The energy demand can be mitigated easily with the available renewable source. The companies also get benefitted with this technology in long run. The coming future is definitely filled up with the non conventional resources especially solar technology plays a phenomenal role among the available resources like wind, bio gas, and fuel cell technology etc.

\section{Conclusion}

Solar technology is the better technology available to the consumers. The customers should realize the importance of the technological improvements and must encourage its sales and marketing. The companies should follow the suggestions mentioned in this paper so that they can reach the customers and boost up their sales enhancing their profits. Educating the consumers about the solar marketing will help the companies and in turn the Government to lift the economical status of the country. The solar sales will indeed helps in mitigating the energy crisis which is prevailing in our present day world.

\section{References}

[1] Somasekhar.G, Bharathi.G and GirijaEureka.M, Marketing Methodology of Solar PV packs, IOSR Journal of Economics and Finance (IOSR-JEF), pp: 38-43.

[2] K.R. Ambepitiya, Strategies to promote Solar Power Energy: A Review of Literature, Proceedings of $8^{\text {th }}$ International Research Conference, November 2015.

[3] Raja Peter, B. Ramaseshan, C.V. Nayar, Conceptual model for marketing solar based technology to developing countries, Renewable Energy, Elsevier Science - 25, pp: 511-524, 2002.

IOSR Journal of Business and Management (IOSR-JBM) is UGC approved Journal with S1. No. 4481, Journal no. 46879.

Dr. Gurubheemachar.B. "Strategy Evaluation for accelerating the solar marketing ." IOSR Journal of Business and Management (IOSR-JBM) 19.7 (2017): 60-62. 